\title{
Correction: Is current practice around late termination of pregnancy eugenic and discriminatory? Maternal interests and abortion
}

Savulescu J. Is current practice around late termination of pregnancy eugenic and discriminatory? Maternal interests and abortion. J Med Ethics 2001;27:165-71.

Lachlan de Crespigny contributed in a major way to the conceptualisation, design, administration of surveys, analysis and writing up of this paper. He asked for his name to be removed as an author after submission because of a series of complaints against him which were current at that time but which were later shown to be unfounded. He received legal advice that this paper might compromise his case. He was cleared of any wrong doing and his name should now appear as an author on this manuscript. There are no other authors.

\section{Editor's note}

\section{Julian Savulescu}

This whole affair represented the failure and improbability of practical ethics. In my experience and with a detailed knowledge, Lach de Crespigny is the most thoughtful, conscientious and ethical clinician I have met and had the privilege to work with. He has a passion for ethics and this paper is an illustration of his search for deeper understanding and his care for pregnant women.

(C) Article author(s) (or their employer(s) unless otherwise stated in the text of the article) 2018. All rights reserved. No commercial use is permitted unless otherwise expressly granted.

J Med Ethics 2018;44:132. doi:10.1136/jme.27.3.165corr1

Check for updates 